\title{
CORRESPONDENCE
}

\section{EXCESSIVE PROLIFERATION OF CORNEAL EPITHELIUM}

\section{To the Editorial Committee of the British Journal of OPHTHALMOLOGY}

SIRS,-I was interested to read in the September issue the description by Dr. G. S. Sihota (Brit. J. Ophthal., 1965, 49, 497) of a soldier's eye which showed massive fibrinous exudate on the conjunctiva and corneal epithelium.

The facts that direct smear and culture from the conjunctival sac were negative for pathogenic organisms, and that in spite of recurrent membrane-like growths on the conjunctiva and cornea, vision of $6 / 9$ was ultimately retained, suggest that it was a case of self-inflicted conjunctivitis and not due to any pathogenic organism.

These cases when first seen, or when one sees only an isolated case, are very puzzling. I well remember the first time I saw one in Quetta. I diagnosed it as membranous conjunctivitis, in spite of negative bacteriological findings. It was not until I moved shortly afterwards to Assam and saw some hundreds of these cases that I realized that they were, in fact, self-inflicted. The cases were reported by me in the British Journal of Ophthalmology, 1945, 29, 196.

At that time we proved that most of the cases were due to the irritant substances found in jequirity seeds (Abrus precatorius) or castor oil seeds (Ricinus communis), which are readily available in many parts of India.

FULWITH House, Yours faithfully,

5 FULWITH ROAD, E. J. SOMERSET HARROGATE, YORKSHIRE.

October 22, 1965.

\section{NOTES}

\section{UNIVERSITY OF TORONTO}

The Eye Department, University of Toronto, is holding its Annual Surgical Refresher Course in conjunction with the Walter Wright Day and Alumni Meeting from February 16 to 18, 1966. Guest speakers on the course will be Dr. Angus McLean and Dr. Richard Troutman. Dr. Lorenz Zimmerman will give the Walter Wright Lecture.

The Surgical Course will take place during the first two days and the central theme will be surgical techniques and complications of surgery, illustrated with movies. On the third day the Course will continue with a pathological seminar in the morning and will feature the Walter Wright Lecture in the afternoon.

Saturday, February 19, will open with a Grand Ward Rounds, with presentation of cases and discussion by Dr. Zimmerman, and will continue with presentation of papers by the Alumri.

Registration for the Course is $\$ 60.00$ ( $£ 1910$ s.). Registration for the Walter Wright Leoture is free and may be made at the time of attendance.

A Course in Ophthalmology for General Practitioners will be given on March 17 and 18, 1966. This is to acquaint the general practitioner with ophthalmic problems such as sudden causes of blindness, ocular trauma, infection, glaucoma, etc., and will include subjects as requested by practitioners.

Registration for the course is $\$ 30.00$ ( $£ 915 s$.). All registrations may be made through Dr. R. I. Macdonald, Division of Postgraduate Medical Education, University of Toronto.

\section{EDRIDGE-GREEN LECTURE}

The Edridge-Green Lecture will be given by Prof. $O$. Whitteridge in the Royal College of Surgeons on Friday, February 11, 1966, at 5 p.m. His subject is "The Structural Basis of Visual Acuity". 